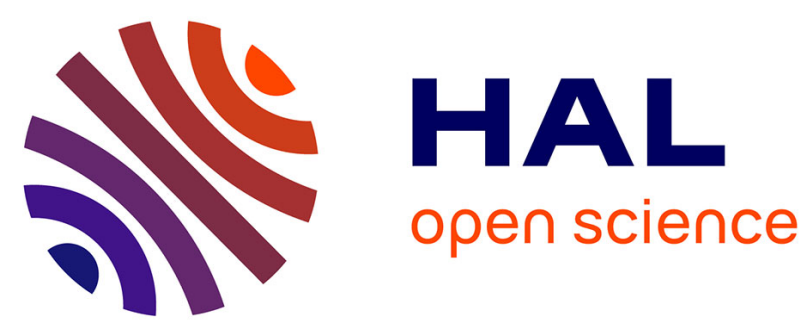

\title{
Spatial distribution of Cubiceps pauciradiatus (Perciformes: Nomeidae) in the tropical Indian Ocean and its importance in the diet of large pelagic fishes
}

Michel Potier, Evgeny Romanov, Yves Cherel, Richard Sabatié, Veniamin Zamorov, Frédéric Ménard

\section{To cite this version:}

Michel Potier, Evgeny Romanov, Yves Cherel, Richard Sabatié, Veniamin Zamorov, et al.. Spatial distribution of Cubiceps pauciradiatus (Perciformes: Nomeidae) in the tropical Indian Ocean and its importance in the diet of large pelagic fishes. Aquatic Living Resources, 2008, 21 (2), pp.123-134. 10.1051/alr:2008026. hal-00307533

\section{HAL Id: hal-00307533 \\ https://hal.science/hal-00307533}

Submitted on 30 May 2020

HAL is a multi-disciplinary open access archive for the deposit and dissemination of scientific research documents, whether they are published or not. The documents may come from teaching and research institutions in France or abroad, or from public or private research centers.
L'archive ouverte pluridisciplinaire HAL, est destinée au dépôt et à la diffusion de documents scientifiques de niveau recherche, publiés ou non, émanant des établissements d'enseignement et de recherche français ou étrangers, des laboratoires publics ou privés. 


\title{
Characterisation of waste output from flow-through trout farms in France: comparison of nutrient mass-balance modelling and hydrological methods
}

\author{
Joël Aubin ${ }^{1, a}$, Aurélien Tocqueville ${ }^{2}$ and Sadasivam J. Kaushik ${ }^{3}$ \\ ${ }^{1}$ INRA-Agrocampus-Ouest, UMR 1069 Sols, Agronomie et hydrosystème, Spatialisation (SAS), 35000 Rennes, France \\ 2 ITAVI, Institut technique de l'aviculture et pisciculture, 28 rue du Rocher, 75008 Paris, France \\ 3 INRA UMR 1067, NuMeA, Unité mixte de recherche "Nutrition Métabolismes et Aquaculture", Pôle Hydrobiologie, 64310 Saint Pée sur \\ Nivelle, France
}

Received 1st May 2010; Accepted 10 January 2011

\begin{abstract}
Water quality assessment is a key factor in the environmental management of freshwater networks, especially those including fish farms, which need cost-effective operational tools to monitor and control their waste output. In France, current legislation specifies limits in concentrations of dissolved compounds and suspended solids at fish-farm outlets. Despite the development of mass-balance modelling tools, chemical analysis of water (hydrological method) remains the most widely used method. To understand better the environmental impact of trout farms on aquatic ecosystems and to compare waste assessment methods, we monitored 20 commercial flow-through trout farms for $24 \mathrm{~h}$, and we compared data obtained with the two methods (hydrological method and mass balance modelling) by linear regression. For total nitrogen and total phosphorus, the correlation between the two methods was high; thus, considering the uncertainty of both methods, this study was not able to determine which was more accurate. The high correlation between observed ammonia concentrations and predicted total nitrogen emissions provides a coefficient for estimating ammonia emissions at the farm level. The same approach is proposed for the evaluation of phosphate emissions. In conclusion, this study confirms the utility of simulation modelling for assessing nutrient release from fish farms.
\end{abstract}

Key words: Effluent discharge / Nitrogen loading / Phosphorus / Waste / Nutrients / Rainbow trout

\section{Introduction}

Freshwater quality is a matter of increasing concern, both for surface and ground water. Because this essential resource for human beings is considered threatened on a global scale (Millennium Ecosystem Assessment 2005), countries have adopted regulations to protect freshwater and regulate its use. In the European Union, the Water Framework Directive (European Community 2000) has set the objective of "good status" for all water bodies by 2015. In accordance with EU regulations, French law "loi sur l'eau" (Assemblée Nationale \& Sénat 2006) fixed specific goals for the physico-chemical and biological quality of waterbodies in the mid- to longterm. In light of increasingly stricter objectives, questions arise about how to reduce the impact of human activities on these water bodies. To do so, it is essential to have prediction tools and monitoring strategies to assess the impact of diverse activities that are directly linked with freshwater networks, such as fish farming.

\footnotetext{
a Corresponding author: Joel. Aubin@rennes.inra.fr
}

Rainbow trout (Oncorhynchus mykiss) farming has been identified as a significant user of fresh water and is particularly concerned by regulatory changes. As the number of trout farms is low (around 600) compared to other animal farms in France, fish farming suffers from a general lack of knowledge about its economic and environmental implications by citizens and politicians. This situation makes fish farms vulnerable and increases the number of conflicts with the government and other freshwater stakeholders. The combination of environmental constraints and low trout prices has led to the closure of a large number of fish farms. Moreover, trout farms in France are authorised to produce for 30 years; because many of them began operating in the 1970s and 1980s, there is a high demand for authorisation renewals, which will require significant modifications in light of new regulations. Over the past 10 years, trout production in France has decreased by $20 \%$, and the number of farms by approximately $30 \%$ (MAAP 2009).

The environmental impacts of fish farms within aquatic systems are particularly difficult to characterise as they depend on the flow of nutrients associated with physical parameters (e.g., temperature, currents, $\mathrm{pH}$ ) and the sensitivity 
of biological communities within the ecosystem. Existing biological indicators based on invertebrate populations (IBGN; Afnor 2004), macrophytes (IBMR; Afnor 2003), diatoms (IBD; Afnor 2000) or fish (IPR; Afnor 2004) are difficult to implement, however, and require expert knowledge in taxonomy and systematics. Additionally, these biological indices are monitoring tools for the characterisation of ecological quality; they were not initially intended to assess the impact of specific activities.

Although it does not represent the real impact of activities on water bodies, the application of chemical quality standards to fish-farm effluents has been effective monitoring tool for both fish farmers and water quality regulators. Hence, a hydrological method based on the difference in concentrations of selected indicators between the inlet and the outlet of fish farms has been used. Performing periodic water quality analyses to characterise fish-farm effluents, however, is questionable considering the temporal variations that occur on daily (due to feeding and management practices) and yearly scales (due to stocking variations and hydrological and temperature fluctuations of the river) (Cowey and Cho 1991).

Researchers have looked to mathematical models to circumvent these problems. In the 1970s, regression models were developed based on feed use and waste concentrations in salmonid farm outlets (Liao 1970; Willoughby et al. 1972; Liao and Mayo 1974). Later, an improved version of this approach was developed in France (Cemagref 1984), based on earlier nitrogen excretion measurement data (Kaushik 1980). Although these methods give different results (Jatteau 1999), fish farmers and regulators still use them when preparing authorisation documents. Because their parameters are calculated based on the farming system, fish species and feed quality under study it is difficult to generalise their results to other systems. Consequently, this mathematical approach has been adapted for other species and farming systems, but necessitates a large number of observations to be reliable and statistically significant.

In the 1990s, fish nutritionists proposed a mathematical model for the management of aquaculture wastes (suspended matter, nitrogen $(\mathrm{N})$ and phosphorus $(\mathrm{P})$ ) based not on farmoutlet assessment, but on the nutrient utilisation efficiency of feed, using a mass-balance approach (Cho and Kaushik 1990; Cowey and Cho 1991). The scientific principles underlying the model were approach subsequently was validated under controlled conditions (Cho et al. 1991; Boujard et al. 2002; Papatryphon et al. 2005) and can be used for various farmed finfish (Kaushik 1998; Lemarié et al. 1998). The principle is based on the assessment of the difference between the nutrients and digestible energy supplied to fish and their wholebody nutrient and energy gains. The proportion not retained by the fish for growth is released into the water and constitutes the waste emissions of the fish farm. Consequently, feed composition and fish body composition are used to estimate the quantity of $\mathrm{N}$ and $\mathrm{P}$ released into water. Furthermore, taking into account the dry matter and nutrient digestibility of feed allows prediction of the emissions of solids (components ingested but not digested, i.e. faeces) and dissolved matter (digested component which is not retained). Using this method, it is possible to assess the quantities of waste emitted at different time scales (e.g., day, year, production cycle). This approach also has been refined by the inclusion of sub-models (i.e., digestibility, deposition, limnological transformation) aiming to decrease the uncertainty associated with the fate of nutrients (Hua et al. 2008).

The last validation trial of this mass-balance model (trout farms in France) raised questions about values of model coefficients due to differences between model predictions and observed downstream ammonia concentrations (Papatryphon et al. 2005). In response, the present study focuses on subsequent evaluation of model accuracy, comparing model predictions of water quality from 20 commercial trout farms in France with observed data from chemical analysis. The study also compares observations and predictions of $\mathrm{N}$ and $\mathrm{P}$ compounds and suspended solids released by the farms.

\section{Material and methods}

\subsection{Fish farms}

Data were collected during 2007-2008 from 20 French flow-through trout farms selected to cover variability in biophysical contexts (hydro-eco-regions), types of production (pan size, large trout), and size. The farms mainly produced rainbow trout (Oncorhynchus mykiss), but some contained smaller populations of other salmonids such as brown trout (Salmo trutta) and Arctic char (Salvelinus alpinus). We attempted to select farms with similar biophysical and hydrologic characteristics both upstream and downstream, with precise data recording on fish stocks and feeds and total cooperation of farm staff. The farms were located in the following regions of France: 6 in the southwest, 6 in Brittany (west), 3 in Normandy (northwest), 4 in the east, and 1 in the southeast. Annual production ranged from 20 to $670 \mathrm{t}$. Seven were specialised in the production of pan-size trout $(0.25 \mathrm{~kg})$ for consumption or restocking, while 3 produced only large rainbow trout $(>1.8 \mathrm{~kg}$ ) for fillets or processing. The other 10 farms produced fish of variable sizes. The biological feed:gain ratio (FGR), the dry mass of feed distributed divided by the biomass produced (including dead fish), observed over a one year scale, ranged from 1.0 to 1.6. For water treatment at the farm outlet, 6 farms used a drum filter, 4 a sedimentation pond and 10 had a direct discharge.

\subsection{Water quality analysis}

Water quality sampling was carried out once on each farm, at the inlet, the outlet and 100 and $1000 \mathrm{~m}$ downstream from the outlet (data on $1000 \mathrm{~m}$ location samples are not discussed here). Samples of $800 \mathrm{ml}$ were taken each hour for $24 \mathrm{~h}$ (24 samples at each location) using an automatic sampler (Isco ${ }^{\circledR} 3700$ ). Before sampling, each bottle was prepared by adding 6 drops of sulphuric acid (24\%), to obtain a pH level of around 2, thereby avoiding chemical changes in nitrogenous compounds.

After homogenisation by manual reversal of the bottle, a proportion of each sample was added to a 250-ml bottle for chemical analysis, and to a $500 \mathrm{ml}$ bottle for suspended-solids 
analysis. For 7 farms, chemical analyses were performed on each of the 24 samples. For the other farms, analyses were done on a pool of the 24 samples to obtain average values and on samples associated with the expected minimum nitrogen excretion (before the first meal) and maximum nitrogen excretion ( $6 \mathrm{~h}$ after the last meal) to try to characterise daily variability. All suspended solid assessments were performed on daily pools of 24 samples.

The analytical methods used to evaluate the concentrations of different dissolved compounds were as follows: total $\mathrm{N}$ - mineralisation using potassium peroxodisulphate, then using continuous flow analyser RFA 300 Alpkem ${ }^{\circledR}$ according to ISO 11905-1 (1997); Total ammonia (N-NH4) - according to method ISO 11732 (1997) using a continuous flow analyser RFA 300 Alpkem ${ }^{\circledR}$; Nitrites $\left(\mathrm{N}-\mathrm{NO}_{2}\right)$ and nitrates $\left(\mathrm{N}-\mathrm{NO}_{3}\right)$ according to method ISO 13395 (1996); Total P - mineralisation with potassium peroxodisulphate, then measured according to EN 1189 (1996), using a spectrophotometer Lambda 20 Perkin Elmer ${ }^{\circledR}$; Phosphates $\left(\mathrm{P}_{-}-\mathrm{PO}_{4}\right)$ - EN 1189 (1996) using spectrophotometer Lambda 20 Perkin Elmer ${ }^{\circledR}$. The concentration of suspended solids was assessed according to EN 872 (1996), using 0.45- $\mu \mathrm{m}$ cellulose acetate filters.

Water current flow was measured using an electromagnetic probe (Flo Mate $2000^{\circledR}$ ) at the inlet and the outlet of the farm. In adaptation of NF EN ISO 748 (2009), water speed was recorded on transversal homogeneous sections of the channels. The number of sections depended on channel width, and speeds of all the sections were aggregated. The best estimate of current flow between inlet and outlet (depending on the number of channels and the homogeneity of measurement) was kept for further calculations. This measure was repeated if a modification of flow rate was suspected during the sampling period.

The following farm-management data were collected for the day and the day before water sampling: fish population, biomass of fish sold or that died during the sampling day, quantity and composition of feeds distributed, and meal timing. The following data were collected for the previous year: changes in fish population, biomass of sold and dead fish, and quantity and composition of distributed feed. The hydrological method for nutrient emission estimation at the farms was based on the difference between nutrient ( $\mathrm{N}$ and $\mathrm{P}$ compounds) and suspended solid concentrations in outlet and inlet waters.

\subsection{Nutrient mass-balance modelling}

The quantity of nutrient release was assessed by the difference between $\mathrm{N}$ and $\mathrm{P}$ provided by feed and that retained by fish, using methods adapted from Cho and Kaushik (1990), Papatryphon et al. (2005) and Roque d'Orbcastel et al. (2008). Information provided by feed manufacturers was used to quantify levels of nutrients in feed. The quantity of $\mathrm{N}$ and $\mathrm{P}$ retained in fish was obtained by multiplying body mass by speciesspecific concentrations $\left(0.0256 \mathrm{~kg} \mathrm{~N} \mathrm{~kg}^{-1}\right.$ as per Bureau et al. 2002; $0.004 \mathrm{~kg} \mathrm{P} \mathrm{kg}^{-1}$ as per Bureau and Cho 1999). We chose to use the average annual FGR of each farm to calculate body mass gain from distributed feed. This value seemed to be the more reliable information available in every farm considering the uncertainty on the fish stocks present on the day of study.
Table 1. Digestibility of nutrients in trout feeds used in the study.

\begin{tabular}{lc}
\hline Component & Digestibility (\%) \\
\hline Protein & 92 \\
Fat & 95 \\
Carbohydrates & 71 \\
Fibres & 0 \\
Ash & 50 \\
Phosphorus & 50 \\
\hline
\end{tabular}

To estimate the amount of feed ingested, a coefficient of feed loss was applied (5\% for most farms, but $10 \%$ when the FGR exceeded $20 \%$ of the level expected for size and species). This factor influences the solid emissions of the farm and is mitigated by water treatment facilities. The $\mathrm{N}$ and $\mathrm{P}$ contained in non-ingested feed were taken into account in the calculation of solid and total wastes.

The proportion of dissolved and solid fractions emitted by fish was estimated from the digestibility of feed components (Table 1). Some of the solid fraction emitted by fish stems from faecal wastes, reflecting the undigested portion of ingested feed. For the $\mathrm{N}_{-} \mathrm{NH}_{4}$ fraction of the emitted N, a standard factor of 0.8 was applied (Kaushik and Cowey 1991). To estimate the quantity of nutrients and solids released into the river by a farm, a retention coefficient was used to characterise the efficiency of the water-treatment system $(30 \%$ of solids for drum filters, $60 \%$ of solids for the large sedimentation ponds, and $0 \%$ for direct discharge). The quantity of extracted solids and their nutrient contents were subtracted from the waste calculation. Estimation of average nutrient concentrations was obtained by dividing nutrient quantities by the daily cumulative water flow.

\subsection{Comparison of methods}

We compared predicted mass-balance model values (calculated on a one-day scale) from observed hydrological values (the difference between mean outlet and inlet concentrations) using linear regression, for the 20 farms. The error associated with the hydrological analysis was estimated as the measurement error associated with the chemical analyses. As this error depends on the concentration of the analysed nutrient, it differed from one farm to another. The statistical analysis was conducted iteratively, beginning with regression analysis of all 20 farms. At each iteration, any outliers (farms with Pearson's normalised residuals $>2$ or $<-2$ ) were removed and regression recalculated for the remaining farms.

\section{Results}

\subsection{Water-quality analysis}

Observed concentrations of nitrogenous compounds showed large variability among farms in terms of the ambient $\mathrm{N}$ concentration in the river (Table 2). We observed a factor of 30 between the minimum and maximum total nitrogen $\left(N_{\text {tot }}\right)$ concentrations at the farm inlet, due primarily to $\mathrm{N}-\mathrm{NO}_{3}$ concentrations ranging from 0.12 to $9.92 \mathrm{mg} \mathrm{L}^{-1}$. Consequently, 
Table 2. Summary data from the hydrological analysis approach on the concentration of nitrogen and phosphorus compounds and suspended solids (SS) at the inlet, outlet, and $100 \mathrm{~m}$ from the outlet of 20 trout farms. The average farm contribution represents the percentage of compounds emitted by the farm relative to the river concentration, measured $100 \mathrm{~m}$ downstream from the outlet.

\begin{tabular}{|c|c|c|c|c|c|c|c|c|}
\hline $\begin{array}{l}\text { Sampling } \\
\text { Location }\end{array}$ & & $\begin{array}{c}N_{\text {tot }} \\
\left(\mathrm{mg} \mathrm{L}^{-1}\right)\end{array}$ & $\begin{array}{c}\mathrm{N}-\mathrm{NH}_{4} \\
\left(\mathrm{mg} \mathrm{L}^{-1}\right) \\
\end{array}$ & $\begin{array}{c}\mathrm{N}-\mathrm{NO}_{3} \\
\left(\mathrm{mg} \mathrm{L}^{-1}\right) \\
\end{array}$ & $\begin{array}{c}\mathrm{N}-\mathrm{NO}_{2} \\
\left(\mathrm{mg} \mathrm{L}^{-1}\right)\end{array}$ & $\begin{array}{c}P_{\text {tot }} \\
\left(\mathrm{mg} \mathrm{L}^{-1}\right)\end{array}$ & 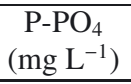 & $\begin{array}{c}\mathrm{SS} \\
\left(\mathrm{mg} \mathrm{L}^{-1}\right) \\
\end{array}$ \\
\hline \multirow{3}{*}{ Inlet } & Mean & 4.47 & 0.11 & 3.71 & 0.02 & 0.07 & 0.05 & 9.29 \\
\hline & Min. & 0.38 & 0.01 & 0.12 & 0.00 & 0.01 & 0.01 & 1.32 \\
\hline & Max. & 10.81 & 0.32 & 9.92 & 0.08 & 0.16 & 0.11 & 22.00 \\
\hline \multirow[t]{4}{*}{ Outlet } & Mean & 4.95 & 0.44 & 3.77 & 0.03 & 0.17 & 0.10 & 12.86 \\
\hline & Min. & 0.72 & 0.15 & 0.18 & 0.00 & 0.04 & 0.02 & 4.78 \\
\hline & Max. & 10.99 & 1.26 & 9.9 & 0.16 & 1.09 & 0.29 & 27.00 \\
\hline & Mean & 4.87 & 0.36 & 3.76 & 0.04 & 0.13 & 0.09 & 15.15 \\
\hline $100 \mathrm{~m}$ & Min. & 0.63 & 0.11 & 0.21 & 0.00 & 0.02 & 0.02 & 3.43 \\
\hline \multirow[t]{2}{*}{ Downstream } & Max. & 11.38 & 0.89 & 9.98 & 0.16 & 0.33 & 0.20 & 37.00 \\
\hline & Average farm contribution at $100 \mathrm{~m}$ & $14 \%$ & $68 \%$ & & & $47 \%$ & $44 \%$ & $39 \%$ \\
\hline
\end{tabular}

the contribution of farms to the ambient $\mathrm{N}$ concentration $100 \mathrm{~m}$ downstream from the outlet varied from $0-73 \%$ (mean $=14 \%)$. Among the farms, the difference between the inlet and outlet concentrations of Ntot ranged from 0.016 to $1.134 \mathrm{mg} \mathrm{L}^{-1}$, due primarily to the concentration of $\mathrm{N}_{-} \mathrm{NH}_{4}$, which varied on average $0.11 \mathrm{mg} \mathrm{L}^{-1}$ in the inlet and $0.44 \mathrm{mg} \mathrm{L}^{-1}$ in the outlet. This variation remained low for $\mathrm{N}-\mathrm{NO}_{3}$ and $\mathrm{N}-\mathrm{NO}_{2}$. The difference between inlet concentrations of the sum of $\mathrm{N}-\mathrm{NO}_{2}$ and $\mathrm{N}-\mathrm{NO}_{3}$ reached a mean of $0.08 \mathrm{mg} \mathrm{L}^{-1}$ (range: -0.45 to $1.20 \mathrm{mg} \mathrm{L}^{-1}$ ), with 9 farms displaying negative values. There was no correlation between concentrations of $N_{\text {tot }}$ and $\mathrm{N}-\mathrm{NO}_{2}+\mathrm{N}-\mathrm{NO}_{3}$. The $\mathrm{N}^{-\mathrm{NH}_{4}}$ concentration in the water ranged from 0.08 to $1.24 \mathrm{mg} \mathrm{L}^{-1}$ in the outlet (mean: $0.34 \mathrm{mg} \mathrm{L}^{-1}$ ). It represented an average of $68 \%$ of the mean $\mathrm{N}-\mathrm{NH}_{4}$ contribution to the river (range: 16-97\%).

The concentrations of phosphorus compounds were lower than those of nitrogen compounds: total phosphorus $\left(P_{\text {tot }}\right)$ concentration ranged from 0.01 to $0.16 \mathrm{mg} \mathrm{L}^{-1}$ in the inlet, and 0.04 to $1.09 \mathrm{mg} \mathrm{L}^{-1}$ in the outlet, which represented a mean contribution of $47 \%$ to river $P_{\text {tot }}$. The mean contribution to river $\mathrm{P}-\mathrm{PO}_{4}$ concentration was similar on average (44\%), with concentrations ranging from 0.02 to $0.29 \mathrm{mg} \mathrm{L}^{-1}$ in the outlet. The suspended solids concentrations varied widely, especially in the inlet $\left(1.32\right.$ to $\left.22.00 \mathrm{mg} \mathrm{L}^{-1}\right)$. The average contribution of the farms to river suspended solids was $39 \%$.

\subsection{Nutrient mass-balance modelling}

The estimation of the nutrient emissions by the trout farms using mass-balance modelling showed a large variability. The mean predicted contribution of the farms to $N_{\text {tot }}$ concentration in the river was $0.61 \mathrm{mg} \mathrm{L}^{-1}$, ranging from 0.18 to $1.56 \mathrm{mg} \mathrm{L}^{-1}$. Consequently, the average $\mathrm{N}^{-\mathrm{NH}_{4}}$ contribution, calculated using the factor of 0.8 , was $0.49 \mathrm{mg} \mathrm{L}^{-1}$ ranging from 0.14 to $1.25 \mathrm{mg} \mathrm{L}^{-1}$. Farm contribution to river $P_{\text {tot }}$ reached $0.07 \mathrm{mg} \mathrm{L}^{-1}$ on average, ranging from 0.02 to $0.13 \mathrm{mg} \mathrm{L}^{-1}$, with a P-PO4 contribution of $0.01 \mathrm{mg} \mathrm{L}^{-1}$ on average, ranging from -0.04 to $0.05 \mathrm{mg} \mathrm{L}^{-1}$. The suspendedsolids contribution of the farms reached $2.36 \mathrm{mg} \mathrm{L}^{-1}$ on average, ranging from 0.65 to $6.50 \mathrm{mg} \mathrm{L}^{-1}$.

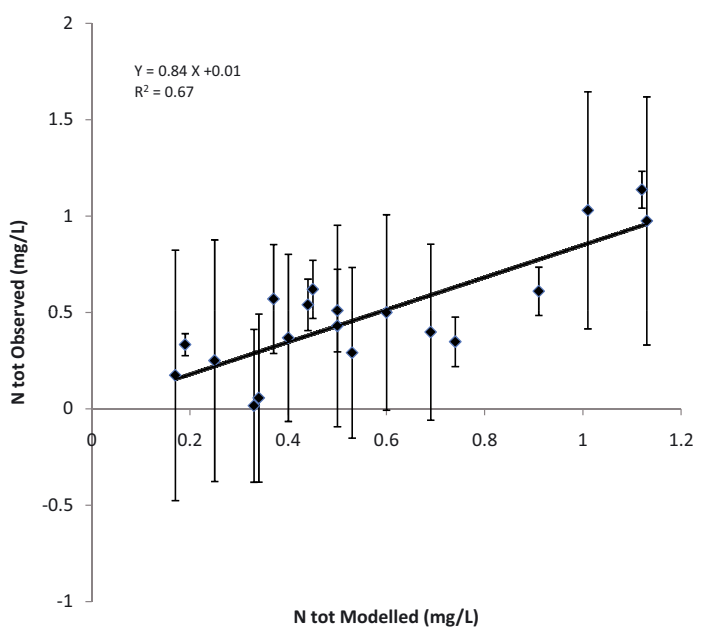

Fig. 1. Linear regression of observed total $\mathrm{N}$ concentrations (hydrological method) on predicted total $\mathrm{N}$ concentrations (mass-balance method) for 19 trout farms in France. Error bars indicate the uncertainty associated with chemical analyses. $Y=0.84 X+0.01$ with $R^{2}=0.67$.

\subsection{Comparing the hydrological method and the mass- balance approach}

For N compounds, predicted and observed $N_{\text {tot }}$ concentrations $(n=19)$ showed a significant $\left(R^{2}=0.67 ; p<0.0001\right)$ correlation (Fig. 1). Both predicted N-NH$H_{4}$ and $N_{\text {tot }}$ concentrations $(n=18)$ showed a strong and significant $\left(R^{2}=0.80\right.$; $p<0.0001)$ correlation with observed $\mathrm{N}-\mathrm{NH}_{4}$ concentrations (Figs. 2 and 3). As for $P$ compounds, predicted and observed $P_{\text {tot }}$ concentrations $(n=18)$ showed a relatively strong $\left(R^{2}=0.58 ; p<0.001\right)$ correlation (Fig. 4$)$. In contrast, there was no correlation $\left(R^{2}=0.07\right)$ between predicted and observed $\mathrm{P}_{-} \mathrm{PO}_{4}$ concentrations $(n=17)$. There was, however, a significant $\left(R^{2}=0.42 ; p<0.005\right)$ correlation between predicted Ptot concentrations and observed $\mathrm{P}-\mathrm{PO}_{4}$ concentrations, with a slope of 0.58 (Fig. 5). Finally, there was no correlation $\left(R^{2}=0.1\right)$ between predicted and observed suspended solid concentrations (Fig. 6). 


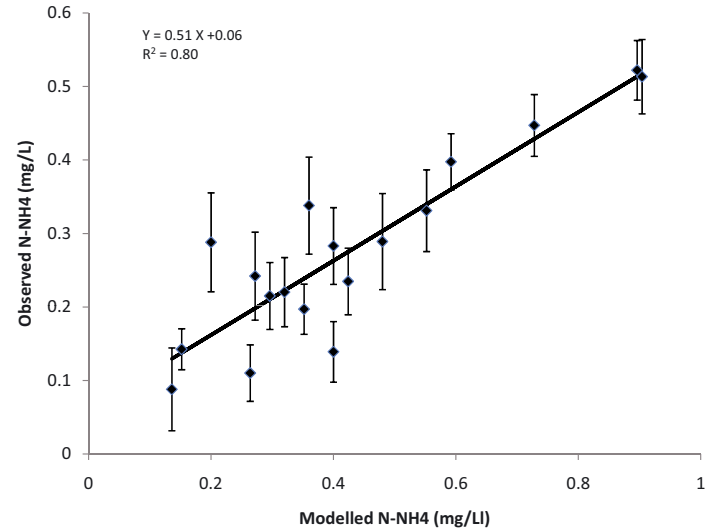

Fig. 2. Linear regression of observed ammonia concentrations (hydrological method) on predicted ammonia concentrations (mass-balance method) for 18 trout farms in France. Error bars indicate the uncertainty associated with chemical analyses. $Y=0.51 X+0.06$ with $R^{2}=0.80$.

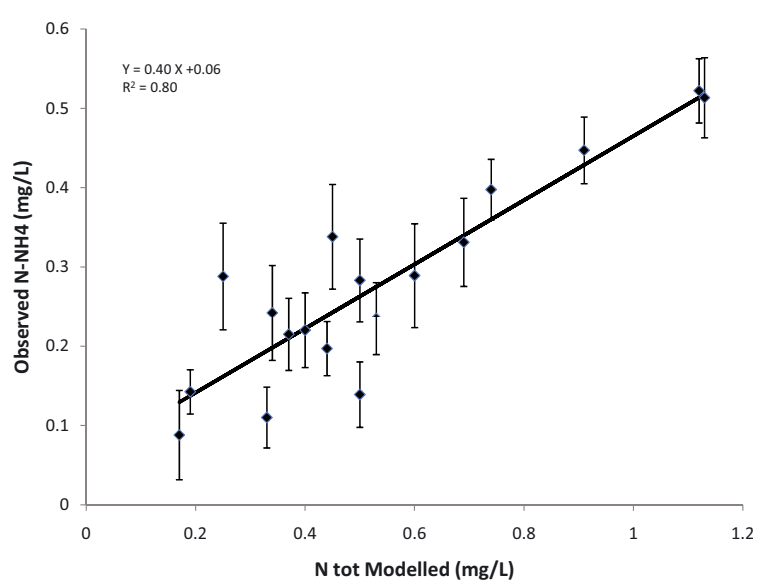

Fig. 3. Regression of observed ammonia concentrations (hydrological method) on predicted total $\mathrm{N}$ concentrations (mass-balance method) for 18 trout farms in France. Error bars indicate the uncertainty associated with chemical analyses. $Y=0.40 X+0.06$ with $R^{2}=0.80$.

\section{Discussion}

It was not possible to keep all the farms in the analysed sample. We removed some of them based on analysis of the normalised Pearson's residuals. We proposed hypotheses to explain why these farms were suspect points in each linear regression.

In the $N_{\text {tot }}$ regression, Farm P14 was detected as suspect. The hydrology of this small farm (20 t) led to a high uncertainty in the results due to several inlets of varying water qualities and the presence of fishing ponds between the farm and the outlet.

In the $\mathrm{N}-\mathrm{NH}_{4}$ regression, two farms were detected as suspect. One was associated with the same farm (P14) that was removed in the $N_{\text {tot }}$ regression analysis. The second was associated with a large farm (P11) where the inlet flow was mainly supplied by a natural spring with a large sedimentation pond for water treatment. The potential ammonia emissions of

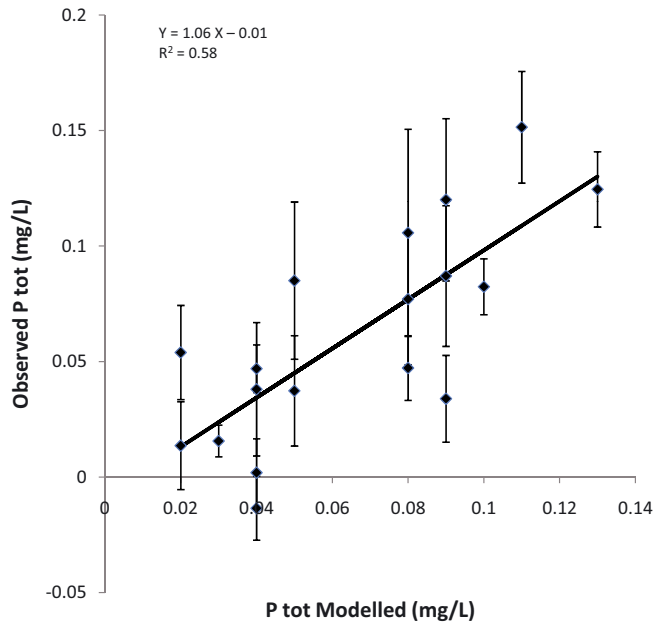

Fig. 4. Regression of observed total $\mathrm{P}$ concentrations (hydrological method) on predicted total P concentrations (mass-balance method) for 18 trout farms in France. Error bars indicate the uncertainty associated with chemical analyses. $Y=1.06 X+0.01$ with $R^{2}=0.58$.

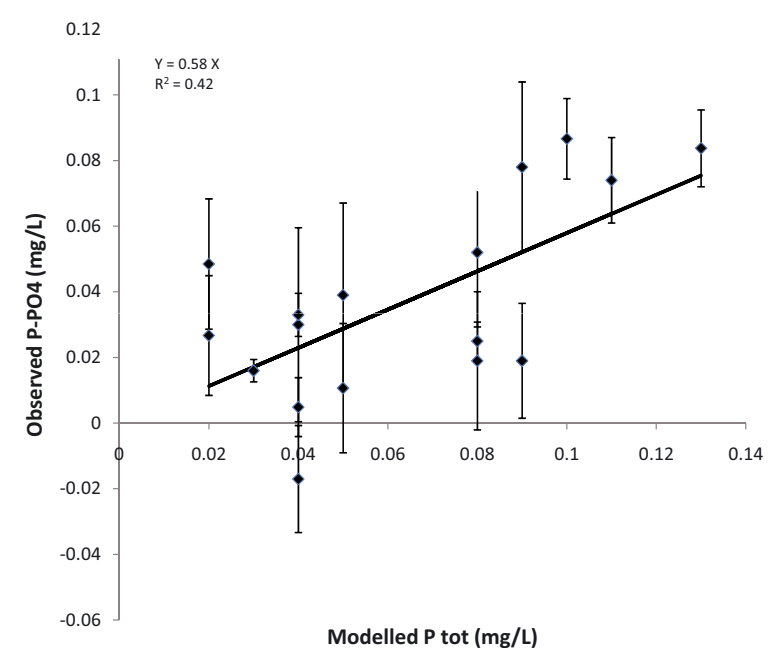

Fig. 5. Regression of observed phosphate-P concentrations (hydrological method) on predicted total P concentrations (mass-balance method) for 17 trout farms in France. Error bars indicate the uncertainty associated with chemical analyses. $Y=0.58 X$ with $R^{2}=0.42$.

the sedimentation pond and mixing of different water sources might partly explain its suspect status. In the $P_{\text {tot }}$ regression, the suspect point was associated with one farm (P3) which uses a decantation pond (in addition to a drum filter, which was not in use at the day of the survey) and where the sludge is digested by a specific bacterial supplement. Additionally, a part of the fish processing plant effluent seems to go through this pond. Farm P14, previously removed from the nitrogenous compounds analysis, was characterised by a suspect point too. In the $\mathrm{P}_{-} \mathrm{PO}_{4}$ regression, the distribution of residuals was not homogeneous. The relationship between observed and modelled concentrations of emitted $\mathrm{P}-\mathrm{PO}_{4}$ does not seem sufficient, with the presence of negative values indicating non-negligible evolution of phosphorus compounds within the farms. 


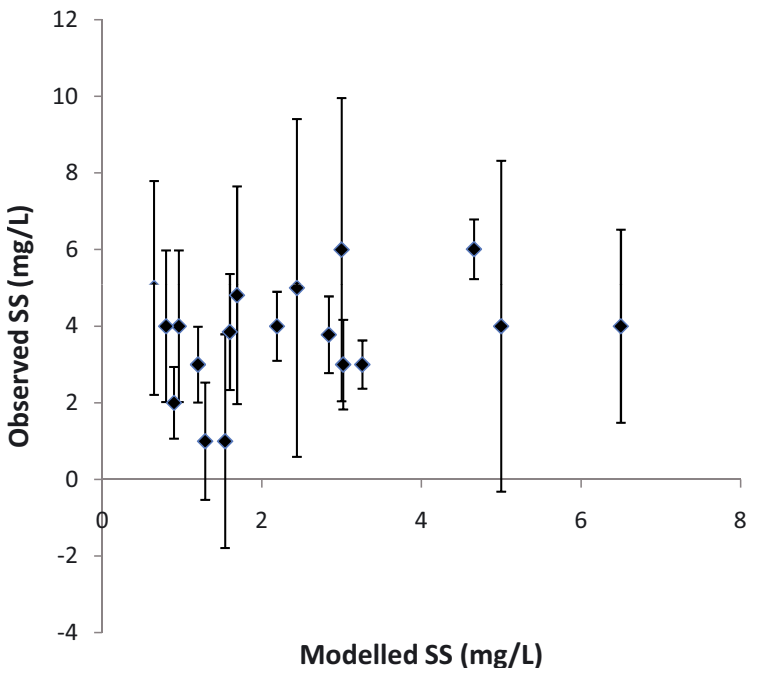

Fig. 6. Regression of observed suspended solids concentrations (hydrological method) on predicted suspended solids concentrations (mass-balance method) for 18 trout farms in France. Error bars indicate the uncertainty associated with chemical analyses.

In the $\mathrm{P}_{-} \mathrm{PO}_{4}$ vs. $P_{\text {tot }}$ regression, one farm (P4) seemed suspect. The natural suspended solids concentration in the river water and the presence of filters at the outlet (which seemed not to be in use during the day of sampling) were amongst the possible causes of this result. This farm was eliminated from the sample.

In the suspended solids regression, the first residual check showed one suspect point associated with farm P20. The inlet water of this farm had a high level of suspended solids and the sedimentation in the rearing tanks induced a decrease in this parameter between the inlet and the outlet. This farm was eliminated from the analysis. The second round of analysis showed another suspect residual associated with farm P5. On this farm, the high level of suspended solids released could be explained by the poor sedimentation system at the outlet which was full and possibly emitted more suspended solids than those produced daily on the farm. This farm was eliminated from the next regression analysis.

This step of removing farms from the statistical analysis how illustrates the variability in the management (especially in hydraulic and water treatment) may influence the quality of impact assessment.

The farm scale often is often considered a black box, with uncertainties associated with rearing management, hydraulic characteristics of pools and drains, and temporal variations in excretion and oxygen consumption. Facing this diversity, the mass-balance modelling method takes into account few parameters: feed quality and quantity, FGR and characteristics of solid retention in the water-treatment systems. We deliberately chose to reduce the number of parameters to ones which are easily available on production sites. However, many sources of uncertainty are associated with both assessment methods. In the hydrological method, one level of uncertainty is associated with sampling, especially its location in time and space. We paid special attention to the location of the automatic sampling equipment, especially due to mixing of water from different sources at the farm outlet. The 100-m sample point represents a compromise between the distance set by regulatory requirements and the distance at which the effluents are considered to be well-mixed with downstream river flow. Nevertheless, we cannot exclude incomplete mixing of water as a source of uncertainty, which may increase with successive reductions in sample volume $(800 \mathrm{ml}$ in the sampler, $250 \mathrm{ml}$ sent to the laboratory, a few $\mathrm{ml}$ used for chemical analysis). This factor is less important for dissolved compounds than for suspended fractions, which experiences much heterogeneity in its concentration in the water column. This is especially the case for aggregates of faeces or uneaten feed which are released at variable intervals by fish farms and are difficult to measure using standard sampling methods, as previously shown by different authors (Cripps 1995; Axler et al. 1997; Cripps and Bergheim 2000; Maillard et al. 2005; Roque d'Orbcastel et al. 2008). The capture of these suspended solids, which pass sporadically into the effluent, is therefore difficult using automatic samplers that take only one sample per hour. The uncertainty associated with chemical analysis also can be significant, but this does not completely explain the variability in the results.

In the mass-balance method, uncertainty in the accuracy of results seems to be due primarily to uncertainties in the accuracy of input data. First, accurate information about the size of fish populations and the quantity of distributed feed varied widely among farms. In addition, we assumed that the FGR on the day of sampling was equal to the average annual FGR observed over the previous year. The uncertainty associated with FGR, however, seemed lower than that associated with the size of the fish population on the sampling day. Nevertheless, we cannot exclude differences in FGR, either due to differences in farm management (e.g., husbandry, water quality, temperature) or to differences in distribution of fish size-class on the day of sampling. Parameter values stemming from expert knowledge, such as nutrient digestibility, fraction of non-ingested feed and solid retention efficiency of watertreatment devices, were adapted to each individual farm. Additionally, the nutrient composition of feed on labels can differ from declared compositions, inducing further uncertainty. Another source of uncertainly with the mass-balance method comes from the conversion of nutrient quantities into concentrations, based on estimates of water flow, which can be particularly difficult to obtain. Lack of accurate hydrological data can also influence estimates of the hydrological method. The electromagnetic water-current flow meter we used claims to have a $2 \%$ measurement error, but considering non-linear flow and the turbulence observed at most of the sites, this uncertainty could reach $20 \%$. Consequently, water flow measurement could have been the main source of uncertainty when comparing the results of these two methods.

Despite these sources of uncertainty, the strong correlation observed between the $N_{\text {tot }}, P_{\text {tot }}$ and $\mathrm{N}_{-} \mathrm{NH}_{4}$ results seems to confirm common robustness for the farms studied. However, it is difficult to attribute a higher level of accuracy to one method over the other. The slope of the regression line for total $\mathrm{N}$ concentration (0.84) indicates that the mass-balance model tends to estimate higher total $\mathrm{N}$ concentrations than the hydrological method, a result consistent with the observations of Roque d'Orbcastel et al. (2008). The low or negative concentrations 
of $\mathrm{N}-\mathrm{NO}_{2}+\mathrm{N}-\mathrm{NO}_{3}$ measured by the hydrological method suggest that nitrification and denitrification occurred within the farms, but the data do not allow us to quantify this phenomenon. In addition, there was no correlation between the $\mathrm{N}$ $\mathrm{NO}_{2}+\mathrm{N}-\mathrm{NO}_{3}$ concentrations observed and any of the recorded parameters. Therefore, the difference in total $\mathrm{N}$ concentrations between the two assessment methods seems consistent with a hypothesis of transfer of $\mathrm{N}$ into the air (as $\mathrm{N}_{2}, \mathrm{NO}, \mathrm{N}_{2} \mathrm{O}$ or $\mathrm{NH}_{3}$ ), as observed in other fish-farming systems (Aubin et al. 2006). Moreover a simple difference between real and declared protein content of the feed may explain a part of the uncertainty. The slope of the regression between predicted and observed $\mathrm{N}-\mathrm{NH}_{4}$ concentrations (0.51) suggests a clear higher estimation by the modelling approach, as observed by different authors (Papatryphon et al. 2005; Roque d'Orbcastel et al. 2008). This result suggests that the given proportion of ammonia in the total $\mathrm{N}$ excreted by salmonids $(0.8)$, as proposed by Kaushik and Cowey (1991), is difficult to apply at the farm level. Compared to data obtained at the experimental scale, which reflects the biological output from the fish, studies at the farm level imply a poor understanding of the evolution of $\mathrm{N}$ subject to microbiological activity (e.g., transformation of ammonia into nitrites and nitrates). Therefore, the relationship between observed ammonia and predicted total $\mathrm{N}$ emitted could be: $\left[\mathrm{NH}_{4}\right]=0.51\left[N_{\text {tot }}\right]+0.08$. This result needs to be confirmed by further observations.

The correlation between the two assessment methods for emitted $P_{\text {tot }}$ is weaker $\left(R^{2}=0.58\right)$ than that for $N_{\text {tot }}$ but has a slope near 1 , indicating that the two methods are statistically comparable. Despite the strong correlation between predicted $P_{\text {tot }}$ emissions and observed $\mathrm{P}-\mathrm{PO}_{4}$ emissions, the correlation between $\mathrm{P}_{-} \mathrm{PO}_{4}$ emissions of each method was weak. This observation indicates that uncertainty in the actual $\mathrm{P}$ content of the feed, the P digestibility in the feed or the dissolved $P$ fraction released from fish does not allow for robust predictions of observed $\mathrm{P}_{-} \mathrm{PO}_{4}$. The use of different $\mathrm{P}$ sources in the diet (plant and fish based), combined with the possible addition of enzymes (phytases) in some feeds can explain a part of this uncertainty. This hypothesis is consistent with the results of Bureau and Cho (1999), which showed that P digestibility highly influenced the dissolved $\mathrm{P}$ emissions of rainbow trout. As proposed by Hua and Bureau (2006) and Hua et al. (2008), model predictions could be improved by considering $\mathrm{P}$ availability of the different feed components. Unfortunately, precise feed composition was not available at the beginning of this study. This improvement has to be applied in further validation work on P emissions. Moreover the complexity of organic matter and solids dynamics, closely associated with those of $\mathrm{P}$ compounds, can influence the ratio between solid and dissolved P fractions. The existence of successive stages of sedimentation and release of solids from the farm could explain the difference in results between a mass-balance approach and one-off chemical analyses, especially for suspended solids. This aspect takes into account leaching and solubilisation factors (Hua et al. 2008), but still does not decrease uncertainties influencing estimates of soluble $\mathrm{P}$ emissions.

Nevertheless, the strength of the regression between predicted $P_{\text {tot }}$ and observed $\mathrm{P}_{-} \mathrm{PO}_{4}\left(R^{2}=0.42\right)$ allows us to propose a factor of 0.58 (the slope) between observed $\mathrm{P}_{-} \mathrm{PO}_{4}$ and predicted $P_{\text {tot }}$ emitted at the farm outlet $\left(\left[\mathrm{PO}_{4}\right]=1.78\left[P_{\text {tot }}\right]\right)$. This value needs to be confirmed by further observations. No correlation between the assessment methods was found for suspended solid emissions, and the data set does not allow us to conclude that one of the assessment methods is more robust than the other, due to the variety of sources of uncertainty associated with each of them (e.g., sampling, hydraulics, farm management). However, Axler et al. (1997) reported that only half of the solids produced within two trout farms were collected in their effluent water. Cho et al. (1991), who faced the same problem, were more confident about results of the massbalance modelling method than those of the hydrological approach due to the latter's sampling bias.

\section{Conclusion}

This study, based on data from 20 farms, confirms the relevance of the mass-balance approach in nutrient emission assessment of flow-through trout farms, as previously shown by other studies (Cho et al. 1991; Boujard et al. 2004; Papatryphon et al. 2005; Roque d'Orbcastel et al. 2008). Regression analysis between the mass-balance modelling and the hydrological method (based on the measurement of concentrations), shows strong comparability; especially for estimates of total $\mathrm{N}$ and total $\mathrm{P}$ emissions. However, the observed proportion of dissolved fractions in the outlet, especially ammonia and phosphates, differs from the expected values (through it is proportional to predicted $N_{\text {tot }}$ and $P_{\text {tot }}$ concentrations, respectively). This observation leads us to propose new factors that could be included in the mass-balance modelling for the calculation of ammonia and phosphate emissions. More observations are required to confirm these factors. Water recycling (partial or total) needs to be investigated to evaluate its influence on the concentration of dissolved $\mathrm{N}$ and $\mathrm{P}$ compounds. Considering the similarity between the two methods, the advantages of mass-balance modelling (less labour and data necessary), and the fact that hydrological methods do not reflect the biological reality of fish emissions, the modelling approach seems to be a cost-efficient solution to estimate the release of waste by fish farms. It is a feasible tool for both fish farmers and authorities monitoring water quality. The use of standard factors for digestibility, feed ingestion ratio, annual FGR and water-treatment efficiency seems sufficient to obtain a robust evaluation of trout farm nutrient release. A more specific evaluation could be made by replacing average factors with farmspecific or feed-specific factors.

Acknowledgements. This study was undertaken as a part of the IDAqua project, funded by CASDAR and FEP and lead by CIPA (Comité Interprofessionnel des Produits de l'Aquaculture) and ITAVI (Institut Technique de l'Aviculture). The authors thank the following people for their invaluable help with data collection and chemical analysis: Yannick Fauvel, Martine Ollitrault, Nadia Snoussi, Mickael Marle, Souhila Amrouch, Tristan Gueneuc, and Miranda Maybank. We also thank the FFA and the fish farmers who participated in this study. The authors warmly thank Michael Corson for the language correction and his suggestions on this article. 


\section{References}

Afnor, 2000, Norme AFNOR NF T90-354 : L'Indice biologique Diatomées

Afnor, 2003, Norme AFNOR NF T90-395 : L'Indice biologique Macrophytes en rivière

Afnor, 2004, Norme AFNOR NF T90-344 : L'Indice Poissons en rivière

Afnor, 2004, Norme AFNOR NF T90-350 : L'Indice biologique global normalisé.

Assemblée Nationale \& Sénat, 2006, Loi n²006-1772 du 30 décembre 2006 sur l'eau et les milieux aquatiques. NOR : DEVX0400302L. J.Off. Rép. Fr. n³03, 31 décembre 2006, texte $\mathrm{n}^{\circ} 3,20285$.

Aubin J., Papatryphon E., Van der Werf H.M.G., Petit J., Morvan Y.M., 2006, Characterisation of the environmental impact of a turbot (Scophthalmus maximus) re-circulating production system using life cycle assessment. Aquaculture;61, 1259-1268.

Axler R.P., Tikkanen C., Henneck J., Schuldt J., McDonald E.M., 1997, Characteristics of effluent and sludge from two commercial rainbow trout farms in Minnesota. Progress. Fish-Cult., 59, 161-172.

Boujard T., Vallée F., Vachot C., 2002, Evaluation des rejets d'origine nutritionnelle par la méthode des bilans, comparaison avec les flux sortants. Proc. 4th workshop on fish nutrition INRAIFREMER, 20 Sept. 2002, Bordeaux, pp. 24-27.

Bureau D.P., Gunther S., Cho C.Y., 2002, Chemical composition and preliminary theoretical estimates of waste outputs of rainbow trout reared in commercial cage culture operations in Ontario. N. Am. J. Aquac. 5, 33-38.

Bureau D.P., Cho C.Y., 1999, Phosphorus utilization by rainbow trout (Oncorhynchus mykiss): estimation of dissolved phosphorus waste output. Aquaculture 179, 127-140.

CEMAGREF, 1984, Salmoniculture et environnement. Vol. 1, Evaluation de la pollution rejetée par les salmonicultures intensives. Etudes 16, 71 p.

Cho C.Y., Kaushik S.J., 1990, Nutritional energetics in fish: energy and protein utilization in rainbow trout (Salmo gairdneri). World Rev. Nutr. Dietetics;1, 132-172.

Cho C.Y., Hynes J.D., Wood K.R., Yoshida H.K., 1991, Quantification of fish culture wastes by biological (nutritional) and chemical (limnological) methods: the development of high nutrient dense (HND) diets. In: Cowey C.B., Cho C.Y. (Eds) Nutritional strategies and aquaculture waste. Proc. 1st Int. Symp. Nutritional Strategies in Management of Aquaculture Waste, University of Guelph, Guelph, Ontario, pp. 37-49.

Cowey C.B., Cho C.Y., 1991, Nutritional strategies and aquaculture waste. Proc. 1st Int. Symp. Nutritional strategies in management of aquaculture waste. Univ. Guelph, Guelph, Ontario.

Cripps S.J., 1995, Serial particle size fraction and characterisation of an aquacultural effluent. Aquaculture 133, 323-339.

Cripps S.J., Bergheim A., 2000, Solids management and removal for intensive land-based aquaculture production systems. Aquac. Eng. 22, 33-56.

European Community, 2000, Directive 2000/60/EC of the European Parliament and of the Council of 23 October 2000 establishing a framework for Community action in the field of water policy. OJL327, 22 Dec. 2000, pp. 1-73.

Hua K., Bureau D.P., 2006, Modelling digestible phosphorus content of salmonid fish feeds. Aquaculture 254, 455-465.
Hua K., de Lange C.F.M., Niimi A.J., Cole G., Moccia R.D., Fan M.Z. , Bureau D.P., 2008, A factorial model to predict phosphorus waste output of rainbow trout (Oncorhynchus mykiss). Aquac. Res. 39, 1059-1068.

Jatteau P., 1999, Les apports trophiques : quantification des flux polluants. In: Petit J. (Ed.) Environnement et Aquaculture : aspects techniques et économiques (Tome 1), INRA Editions, Paris, pp. 74-92.

Kaushik S.J., 1980, Influence of the nutritional status on the daily patterns of nitrogen excretion in carp (Cyprinus carpio L.) and rainbow trout (Salmo gairdneri R.). Reprod. Nutr. Develop. 20, 1751-1765.

Kaushik S.J., Cowey C.B., 1991, Dietary factors affecting nitrogen excretion by fish. In: Cowey C.B., Cho (Eds.) Nutritional strategies and aquaculture waste. Proc.1st Int. Symp. Nutritional Strategies in Management of Aquaculture Waste, University of Guelph, Guelph, Ontario.

Kaushik S.J., 1998, Nutritional bioenergetics and estimation of waste production in non salmonids. Aquat. Living Resour. 11, 211-217.

Lemarié G., Martin J.L., Dutto G., Garidou C., 1998, Nitrogenous and phosphorous waste production in a flow-through land-based farm of European seabass (Dicentrarchus labrax). Aquat. Living Resour. 11, 247-254.

Liao P., 1970, Pollution potential of salmonids fish hatcheries, Water Sewage Works 117, 291-297.

Liao P., Mayo R., 1974, Intensified fish culture combining water reconditioning with pollution abatement. Aquaculture 3, 61-85.

Maillard V.M., Boardman G.D., Nyland J.E., Kuhn D.D., 2005, Water quality and sludge characterization at raceway-system trout farms. Aquac. Eng. 33, 271-284.

MAAP (Ministère de l'Agriculture de l'Alimentation et de la Pêche), 2009, La salmoniculture française à l'étiage, Agreste Primeur 227, June 2009, Paris.

Millennium Ecosystem Assessment, 2005, Ecosystems and Human Well-being: Synthesis.

Island Press, Washington, DC, USA.

NF EN 1189, 1996, Qualité de l'eau, Dosage du phosphore, Dosage spectrométrique à l'aide du molybdate d'ammonium.

NF EN 872, 1996, Qualité de l'eau, Dosage des matières en suspension, méthode par filtration sur filtre en fibres de verre.

NF EN ISO 11905-1, 1997, Qualité de l'eau, Dosage de l'azote, Partie 1 : Méthode par minéralisation oxydante au peroxodisulfate.

NF EN ISO 11732, 1997, Détermination de l'azote ammoniacal par analyse en flux (CFA et FIA) et détection spectrométrique.

NF EN ISO 13395, 1996, Détermination de l'azote nitreux et de l'azote nitrique et de la somme des deux par analyse en flux (CFA et FIA) et détection spectrométrique.

NF EN ISO 748, 2009, Hydrométrie. Mesurage du débit des liquides dans les canaux découverts au moyen de moulinets ou de flotteurs.

Papatryphon E., Petit J., Van der Werf H.M.G., Kaushik S.J., Kanyarushoki C., 2005, Nutrient balance modeling as a tool for environmental management in aquaculture: the case of trout farming in France. Environ. Manage. 5, 161-174.

Roque d'Orbcastel E., Blancheton J.P, Boujard T., Aubin J., Moutounet Y., Przybyla C., Belaud A., 2008, Comparison of two methods for evaluating waste of a flow through trout farm. Aquaculture 274, 72-79.

Willoughby H., Larsen H., Bowen J., 1972, The pollution effect of fish hatcheries. American Fishes and US Trout News, Sept.-Oct. 1972, pp. 6-7 and 20-21. 